\title{
A study on CSR initiatives by corporates in Mysore, Karnataka
}

\author{
Dr. Ashwini J, Dr. Aparna J Varma, Prof. Sudhakar Kulkarni
}

\begin{abstract}
Today businesses are integral part of the society. Corporate social responsibility plays a vital role in winning the customer's confidence that will help growing the business. Many organizations actively conduct campaigns to create awareness among corporate, civic bodies, and government bodies about the importance of corporate social responsibility. According to the Indian Corporate, -Sustainable development implies optimizing financial position while not depleting social and environmental aspects and CSR implies supporting issues related to children, women and environment. This study mainly looks at the various initiatives taken up by Karnataka Bank Ltd, Autoliv and The South India Paper Mills Ltd. By the results we can conclude that CSR at any level is very important for a progressive Corporate culture in the coming days, so that companies give back equally to society. These initiatives need more support and motivation from both the society as well as the Government.
\end{abstract}

Keywords: CSR, corporate culture, sustainable corporate culture, society ethics, Indian corporate Corporate

\section{Introduction}

social responsibility is a process in which all companies come together as one and take part in the welfare of the society. It is often referred to as business responsibility and an organizations action on environmental, social, ethical and economic issues. Companies with high CSR standards are able to demonstrate their responsibilities to the stock holders, employees, customers and the general public. As per United Nations and the European Commission, Corporate Social Responsibility (CSR) leads to triple bottomline: profits, protection of environment and fight for social justice. Economist and philosopher Adam Smith suggested that the needs and desires of society could best be met by the free interaction of individuals and organizations in the marketplace. However, it is still in nascent stage in India. A recent survey reveals that 79 percent of Americans prefer to buy products of companies that actively engage in corporate social responsibility events. In this connection Indian business world should go beyond their economic and legal obligations to establish mutual trust and accept responsibilities related to the betterment of society .Our social responsibility is reflected by the variety of options we take and by our projects to support safety, education, diversity and the environment.-Carlos Ghosn, Chairman and CEO of Renault It has become progressively projected in the Indian corporate setting because organizations have recognized that besides growing their businesses, it is also important to shape responsible and supportable relationships with the community at large. Corporate social responsibility evolved from its early beginnings in the 1950's. CSR as a concept found its feet more in Europe than in the US. CSR is the procedure of assessing an organization's impact on society and evaluating their responsibilities.

The industrial families of the 19th century such as Tata, Godrej, Bajaj, Birla, Singhania were strongly inclined towards economic as well as social considerations. However it has been observed that their efforts towards social as well as industrial development were not only driven by selfless and religious motives but also influenced by caste groups and political objectives. The expectations of the public have grown enormously with demands focusing and forcing companies to take affirmative action. CSR begins with an assessment of the following aspects of each business;

- Customers

- Suppliers

- Environment

- Communities

- Employees

India`s new Companies Act 2013 (Companies Act) has introduced several new provisions which change the face of Indian corporate business" Companies Act 2013 (Companies Act) has introduced several new provisions which change the face of Indian corporate business. One of such new provisions is Corporate Social Responsibility (CSR). The concept of CSR rests on the ideology of give and take. Companies take resources in the form of raw materials, human resources etc from the society. By performing the task of CSR activities, the companies are giving something back to the society. Ministry of Corporate Affairs has recently notified Section 135 and Schedule VII of the Companies Act as well as the provisions of the Companies (Corporate Social Responsibility Policy) Rules, 2014 (CRS Rules) which has come into effect from 1 April 2014. Company (includes foreign company with branches or project in India) having:

DOI: $10.9790 / 487 X-1808014851 \quad$ www.iosrjournals.org $\quad 48 \mid$ Page


- Minimum net worth of rupees 500 crore.

- Turnover up to " 1000 crore rupees"

- Having a net profit of at least ' 5 crore rupees'.

During any financial year, are covered by this provision.

Why corporate social responsibility?

CSR's main aim is to embrace responsibility for the company's actions and encourage a positive impact through its activities on the environment, consumers, employees, communities, stake holders, and all other members of the public spare.

The following are some of the drives pushing business towards corporate social responsibility:

\section{The reducing role of government:}

Reducing government resource, couple with a distrust of regulations, has led to the exploration of voluntary and non-regulatory initiatives instead.

2. Demands for greater disclosure:

Including customers, suppliers, employees, communities, investors and activist organizations.

3. Increased customer interest:

In a recent survey by Environics international, store than one in five consumers reported having either rewarded or punished companies based on their perceived social performance.

\section{Competitive labor markets:}

Employees are increasing the looking behind paychecks and benefits, and seeking out employers whose philosophies and operating practices match their own principles.

\section{Supplier relations:}

as stakeholders are becoming increasingly interested in business affairs, many companies are take themselves in steps to ensure that their partners conduct themselves in a socially responsible manner are introducing codes of conduct their suppliers, to ensure that other companies 'policies or participants do not tarnish their reputation.

\section{The Karnataka Bank Ltd}

Karnataka Bank is committed to identify and support the projects and programs aimed at improving the well beings of the socially and economically disadvantaged sections of the society. This Policy will serve as a guiding document to help identify, execute and monitor CSR projects/programs keeping in mind the spirit of the provision of Section 135 of the Companies Act, 2013 and the rules framed there under. The Policy attempts to adhere to law and best practices in implementing society oriented programs/projects.

\section{CSR Budget}

The overall amount to be committed to CSR project in each financial year in accordance with the provisions of Companies Act, 2013 will be approved by the Board. Within the overall CSR budget, specific CSR initiative/project will be identified by the CSR Support Group in line with the process approved by the CSR Committee of the Board.

\section{Implementation}

In the implementation of CSR initiatives, the Bank will try to adopt participative principle by involving local institutions and community at large based on shared value principle. The CSR Support Group would assist in implementation and monitoring the CSR activities of the Bank. The actual implementation of various CSR activities will be undertaken with the involvement of employees or implementing agencies such as Trust, Societies or companies registered under Section 25 of the Companies Act, 1956/Section 8 of the Companies Act, 2013 or through collaborative projects with other corporate. In case of implementing agency being 'Not profit organization', such an entity shall typically have not less than three years of experience in implementing the CSR initiatives in the respective areas. Based on the Bank`s internal screening criteria, the implementation partner/s will also be screened to ascertain its/their credibility and ability to execute proposed projects

\section{Areas of CSR initiatives:}

The following are the line of activities/initiatives to be undertaken under Bank`s CSR project. This is not an exhaustive list but only an indicative list of areas for CSR intervention which will be reviewed and revised from time to time by the CSR Committee and specific initiative under these will be undertaken in line with the CSR policy to achieve the overall objectives of these interventions

1. Poverty alleviation.

2. Education and employment enhancing vocation skills especially among children, women, elderly and differently abled individuals . 
3. Promoting gender equality, empowering women, setting up of homes and hostels for women and orphans; setting up of old age homes and day care centers.

4. 'Green Initiative'

5. contribution to the Prime Minister`s National Relief or any other fund set up by the Central Government

\section{The South India Paper Mills Limited:}

The Company is consistently taking up various community welfare initiatives for the benefit of people living in the neighboring villages. The Company's CSR activity mainly covers areas situated in and around the factory premises. The CSR Policy aims to promote economic, social, environmental and cultural growth of the community at large in an equitable and suitable manner.

1. Rural development projects: Strengthening rural areas by improving accessibility, drinking water, sanitation, power and livelihoods, thereby creating sustainable villages.

2. Environmental sustainability: Ensuring environmental sustainability, ecological balance, protection of flora and fauna, conservation of natural resources and maintaining the quality of soil, air and water.

\section{Undertaking csr activities}

The Company will undertake its CSR activities, approved by the CSR Committee.

The surplus arising out of the CSR activities, projects or programs shall not form part of the business profit of the Company.

\section{Location of csr efforts}

The CSR committee will decide on the locations for CSR activities

Composition of csr committee

The CSR Committee consists of the following directors:

Mr. Manish M Patel - Chairman

Mr. M G Mohan Kumar - Member

Mr. S R Chandrasekara Setty - Member

\section{Governance \& monitoring process}

The Company will undertake CSR activities as per the provisions of the Companies Act, 2013. The Company will work closely with and support the Board and the CSR Committee in implementing CSR activities of the Company and will assist the CSR Committee in identifying the areas of CSR activities, programs and execution of initiatives as per defined guidelines. The Company will also assist the Board and the CSR Committee in reporting the progress of deployed initiatives and in making appropriate disclosures (internal/external) on a periodic basis.

\section{Autoliv}

As one Autoliv, our corporate social responsibility strategy is to reduce our impact on the environment, develop sustainable products, operate ethically, and be an employer of choice for our employees.

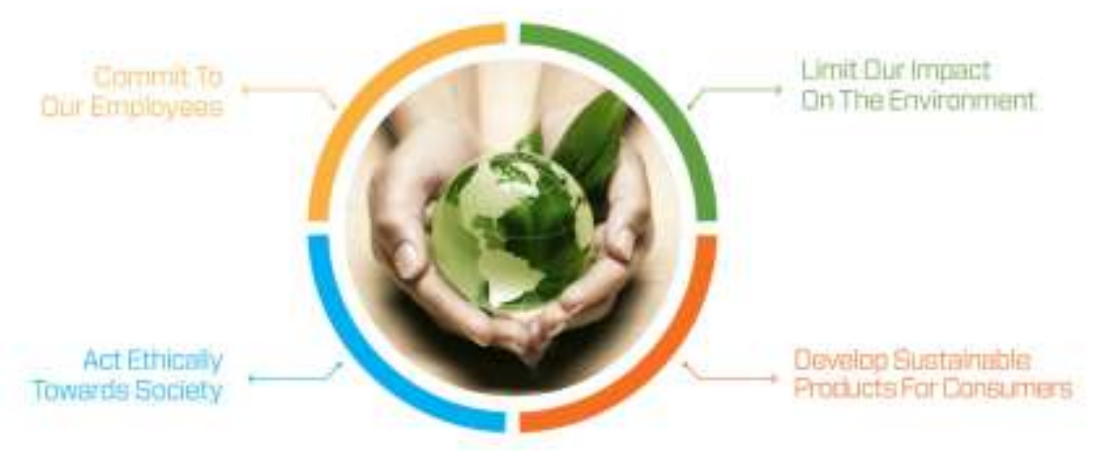

\section{Commit to our employees:}

All over the world, we are committed on behalf of our employees to respecting human rights, diversity, health and safety at work.

\section{Limit our impact on the environment:}

Our commitment is to limit our impact on environment particularly through reducing waste, energy use and water consumption.

Act ethically towards society: 
Our responsibility is based on strict observance of ethical standards, including our suppliers, as well as engaging with the community where we operate.

Develop sustainable products for customers:

Every day we innovate so that we can offer sustainable solutions and save more lives with our products.

\begin{tabular}{|l|l|l|l|l|l|}
\hline KEY Achievements & $\mathbf{2 0 1 1}$ & $\mathbf{2 0 1 2}$ & $\mathbf{2 0 1 3}$ & $\mathbf{2 0 1 4}$ & $\mathbf{2 0 1 5}$ \\
\hline Energy consumption, GWh & 680 & 715 & 771 & 792 & 831 \\
\hline CO2 equivalents metric tons & 230,000 & 246,000 & 257,000 & 268,000 & 290,000 \\
\hline Number of plants with zero injuries & 19 & 13 & 16 & 16 & 22 \\
\hline Code of conduct training, number of associates & 2,389 & 49,614 & 19,115 & 34,898 & 39,257 \\
\hline Autoliv helpline and internal reports & 19 & 86 & 96 & 120 & 127 \\
\hline
\end{tabular}

\section{Conclusion}

Organizations are coming to realize the bottom-line benefits of incorporating sustainability into their DNA. Corporate had moved ahead to a really new level to fulfill their social responsibility which not only helps the society but also to these companies to make a reputation in the society. The expectations from private sector regarding CSR are very high in the future. In today's world companies play an important role in the growth and development of a Country's economic as well as social sector. So it's the government's responsibility to support and motivate the initiatives implemented by the Corporate Sector.

Corporate Social Responsibility is not a fad or a passing trend, it is a business imperative that many Indian companies are either beginning to think about or are engaging with in one way or another. While some of these initiatives may be labeled as corporate citizenship by some organizations, there basic message and purpose is the same.

The overriding conclusion is that companies need to be mature and realize that they must practice socially conscious policies. To conclude CSR as a business imperative must not be accepted grudgingly or half heartedly. Instead, it must be practiced with full vigor and straight from the heart passion and this certainly helps the companies 'in the long run meaningful impact on society and its future is bright in coming years. After all, business is by the people, for the people and of the people.

\section{Reference}

[1]. Corporate Social Responsibility - Towards a Sustainable Future( A White Paper) Kpmg In India

[2]. IOSR Journal of Business and Management (IOSR-JBM) e-ISSN: 2278-487X, p-ISSN: 2319-7668. Volume 16, Issue 5. Ver. III (May. 2014), PP 51-56 www.iosrjournals.org www.iosrjournals.org 51 |Page

[3]. Corporate Social Responsibility: Issues Challenges and Strategies for Indian Firm.

[4]. The South India Paper Mills Limited Cin:L85110ka1959plc001352

[5]. Article by Mansukhlal Hiralal \& Company Mansukhlal Hiralal \& Company dated Updated: 14 January 2015. 